\title{
FINANCIAL LIBERALIZATION AND COLLATERAL REQUIREMENTS OF SMALL AND MEDIUM ENTERPRISES - EVIDENCE FROM SOUTH- EAST ASIAN LOWER AND MIDDLE INCOME COUNTRIES
}

\author{
NGUYEN NGOC THUY VY, NGUYEN THI PHUONG DUNG, NGUYEN KIM QUOC TRUNG \\ Foreign Trade University - Ho Chi Minh City Campus \\ nguyenngocthuyvy.cs2@ftu.edu.vn,nguyenthiphuongdung.cs2@ftu.edu.vn, \\ nguyenkimquoctrung.cs2@ftu.edu.vn
}

\begin{abstract}
Small and medium enterprise (SME) sector is the main motivation for economic growth in developing countries. However, SMEs encounter different challenges in their activities. One of the biggest obstacles facing SMEs is the constraint on their accessibility to external finance due to the lack of collateral. Financial liberalization, through their impact on credit market structure, may affect SMEs' dependence on collateral in accessing external finance. The main purpose of this research is to examine the influence of financial liberalization on collateral requirements of SMEs in South-East Asian lower and middle income countries including Vietnam, Indonesia and Philippines. To be specific, the author uses Probit and Tobit regression with Enterprise Surveys Data of World Bank in 2009 and 2015 to evaluate the effect of financial liberalization on the incidence of collateral loans and the level of collateral requirements. In addition to financial liberalization - our main explanatory variable, we control other factors which may affect SMEs' collateral requirements such as country and firm characteristics. The main result shows that financial liberalization increases the likelihood of collateral requirements.
\end{abstract}

Keywords.collateral, financial liberalization, lower and middle income countries, SMEs.

\section{INTRODUCTION}

In the early 1990s, developing countries began to carry out financial liberalization. The role of financial liberalization in economic growth is the area that has received much attention from the research community. The key point in this study is that financial liberalization is fully conducive to economic growth [2]. [54] and [61], who were pioneers in conducting research which favored financial liberalization, argued that financial liberalization increased the effectiveness of investment (both qualitatively and quantitatively) and boosted the economic growth. However, recent financial crises have made us reconsider the role of financial liberalization [2]. In a report on financial liberalization in 2012, the International Monetary Fund, which previously maintained a consistent point of view that financial liberalization brought benefits, and acknowledged that financial liberalization implies risks. The level of risks increases due to the discord in financial markets. Financial liberalization accompanied by financial constraints has a negative impact on economic growth [3]. [61] argued that financial liberalization does not help solve information asymmetry problems, thus it did not increase the efficiency of financial intermediaries. Other studies, such as [15], also argued that financial liberalization even exacerbates the information asymmetry because it negatively affects credit relations between businesses and banks.

Collateral acts as an indicator for the quality of the business. Mortgages help: (i) mitigate the adverse selection of lenders ( [15]; [16]; [24]); (ii) reduce representation cost between lenders and borrowers; (iii) overcome the issue of under-investment [54]; and (iv) control risk transfer behaviors after signing a loan agreement and thereby addressing ethical risks [16]. Hence, collateral plays the role of protecting the lenders and encouraging them to provide credit to the business. The relationship between financial liberalization and collateral requirements is still vague. Theoretically, financial liberalization may limit the requirements for collateral due to the fact that financial liberalization has a positive impact on the supply of capital (e.g. increasing capital and reducing cost of capital). Financial liberalization, on the other hand, can also make collateral requirements more stringent. The reason is that financial 
liberalization increases information asymmetry, while reducing the quality of credit relationships between enterprises and financial providers. In terms of empirical evidence, studies investigating the impact of financial liberalization on collateral requirements are still rare. [39] is one of the recent studies exploring the impacts of financial liberalization on collateral requirements. However, this study examines the interaction effects of financial liberalization in the relationship between investment and collateral rather than directly examining the impacts of financial liberalization on collateral requirements.

Small and Medium Enterprises (SMEs) are the driving force behind economic growth, especially in developing countries. However, in the process of operation, SMEs face many obstacles. Data from the World Bank's Enterprise Surveys showed that the greatest difficulty in the operation of SMEs is the access to funds [33]. In many cases, financial institutions do not like to provide finance for SMEs because the transaction costs involving in the verification of their credit documents due to their high risk nature. Therefore, collateral is an essential condition for SMEs to access external funding. The role of collateral is particularly important in underdeveloped countries where financial markets are poorly developed with high levels of information asymmetry and poor enforcement [42]. By using the Word Business Environment Survey data, [7] examined the severity of the 12 hurdles about corporate sponsorship that companies encounter. The results show that mortgage requirements are ranked third among the biggest funding hurdles. Surveys conducted in the European Bank for Reconstruction and Development's World Bank and Enterprise Performance Survey and the World Bank for East and Central Asian countries also show that the high demands for collateral is one of the most important reasons why businesses do not have access to external funding.

This study was conducted to examine the impacts of financial liberalization on collateral requirements (on the ability to use collateral in the loan agreement as well as collateral size) in SMEs. The inspiration for the study came from previous research examining factors affecting collateral requirements such as [9], [12], [13], and [52]. However, these studies focus only on SMEs in developed countries while in developing countries with high level of information asymmetry, financial institutions are unlikely to effectively control the risks of businesses, especially SMEs. Information about SMEs is often lacking and less reliable due to few audited financial reports. In addition, weak credit information systems, which are often ignored by small businesses, make it difficult to collect historical data. In addition, the damage caused by bankruptcy in developing countries is often high due to incomplete bankruptcy laws, complex legal procedures and limited financial institutions' ability to recover assets. With these factors, we expect factors effecting the collateral requirements of SMEs in developing countries will be different.

Recently, [33] investigated factors impacting collateral requirements. However, the two studies focused only on East and Central Asian countries and did not take into account the role of financial liberalization. In this study, we analyzed the role of financial liberalization in mortgage requirements. On the sample, we investigated low-income developing countries in Southeast Asia including Vietnam, Indonesia and the Philippines. Some of the reasons for choosing the sample include: (i) Southeast Asia is one of the fastest growing regions in the world; (ii) strong financial liberalization in these countries; and (iii) the lack of serious and comprehensive studies on the impact of financial liberalization on collateral requirements.

In order to achieve the objectives of the study, we first built the model of the factors that impact collateral requirements, including financial liberalization, business characteristics and characteristics of a nation. Next, we used the Probit regression model to test the impact of financial liberalization on the presence of collateral requirements in the loan agreement. To ensure consistency, test results from the probit model will be compared to the results from the Logit model. We then examine the impact of financial liberalization on the mortgage asset size through the Tobit model. In addition to using the financial liberalization index to represent the degree of financial liberalization, we also use capital controls to ensure the sustainability of the results. The paper shows that financial liberalization increases the likelihood of a collateral requirement in a loan agreement. This consequence mainly lies in the fact that financial liberalization influences information asymmetry, and thus stress the need to include the requirement for a collateral. Hence, in the three sample countries, financial liberalization does not lower the difficulty in accessing funds for corporate but it has the opposite pattern. Besides, although the 
regression coefficient of financial liberalization has a positive sign, implying that financial liberalization increases the required collateral size, the impact of financial liberalization on the scale of collateral is not statistical significant.

\section{LITERATURE REVIEW}

\subsection{Financial liberalization}

In the early 1990s, developing countries began to carry out financial liberalization. Financial liberalization refers to government policy to repeal interest rate controls as well as credit control, remove entry barriers for foreign financial institutions, privatize financial institutions, and abolish domestic and foreign financial control measures. In the current theoretical framework, researchers continue to debate the impacts of financial liberalization on the economy. Most of the views advocating financial liberalization are based on Neoclassicalism, which assumes the market is capable of allocating resources efficiently. Debate on financial market liberalization stems from research of [52] and [61]. [52] and [61] criticized government policy control in the contemporary period, such as the setting of a cap on interest rates and credit designation. According to the authors, financial control leads to inefficient and poor allocation of funds, while liberalization of the credit and financial markets is likely to improve the efficiency of capital allocation and stimulate economic growth.

The positive correlation between financial liberalization and economic growth is explained by the following arguments. Firstly, financial liberalization is considered to be able to reinforce market rules and competitiveness in the banking market, thereby raising the savings interest rate which leads to an increase in percentage of savings. Increased savings mean a raise in resources for investment. Second, competition is likely to put pressure on banks' special rate of return on lending rates. With low interest rates, borrowing costs decrease, resulting in an increase in investment and output. Third, financial liberalization extends risk diversification to financial institutions such as banks and investors in the capital markets. Diversifying risk causes lower interest rates and reduces capital costs, thereby reducing funding limits, enabling businesses to invest and help the economy grow. Fourth, if the banking sector is liberalized, banks are motivated to improve operational efficiency by cutting fixed costs, improving management and providing new financial services for the market. In addition, if financial liberalization involves the opening of the domestic banking sector to foreign banks, the domestic banking sector can gain benefits from new banking techniques and risk management as well as new financial instruments and services coming from foreign banks. In general, the arguments suggest that financial liberalization improves the efficiency of financial intermediaries, thereby increasing investment returns and accelerating economic growth.

Contrary to the argument for financial liberalization, some studies suggested that financial liberalization is likely to have a negative impact on the economy through realistic observation of financial liberalization. Expected results lead to financial crises and economic depressions (such as the 2007-2008 economic depression, the financial crisis in Latin America in the 1980s and East Asia in 1997-1998). First, [60] and other researches showed; therefore, it cannot improve the efficiency of financial intermediaries. [62] demonstrated the problem of information asymmetry in financial markets. To put it in other words, financial constraints still exist without government interference. Second, some studies argued that financial liberalization even exacerbated information asymmetry. When the financial market is free with a high level of competition, businesses have more options for low rate credit, and bank borrowing is not favourable anymore. The decline in relationship-based lending negatively affects the quality of the relationship between the business and the bank or, in other words, worsens the bank's information base, thereby increasing information asymmetry in the banking system [20]. Third, increasing competition in the financial markets implies a decline in performance and an increase in the level of sensitivity of financial intermediaries. Reference [20] argued that financial liberalization reduced the commercial value of banks. This decline caused banks to interrupt operations and stimulate them to take risks in order to increase profit under the pressure of reducing the difference between deposit and lending rates. Reduced profit margins due to low lending rates provide incentives for banks to lower the cost of 
approving and managing loans or choosing risky strategies in allocating loans (for example, banks are more concerned about profits than the accompanying risk, so financial liberalization can trigger a crisis if financial liberalization drives banks to take excessive risks under competitive pressure) ( [32]). Finally, the increase in risk appetite in the financial markets together with higher risk of bankruptcy of banks and financial intermediaries may lead to bank-run ( [30]). Bank-run is one of the main factors affecting the stability of financial system.

The above discussion shows that, at least in theory, the nature of the relationship between financial liberalization and economic growth is unclear. With the theoretical ambiguity, the relationship between financial liberalization and economic growth needs to be verified by empirical evidence. However, contrary experimental evidence does not clarify the relationship. Reference [30] showed that most studies did not find convincing evidence of the relationship between financial liberalization and growth. The author criticizes empirical studies without the appropriate testing methods to evaluate the effects of financial liberalization. Reference [30] argued that analyzing the impact of financial liberalization from a business perspective can shed light on the impact of financial liberalization on the real economy rather than on the national level. When considering the impact of financial liberalization through the view of enterprise, [49] conducted a research based on the data collected from 13 developing countries during 1988-1998 and concluded that financial liberalization reduced the funding limits in businesses, especially small businesses.

\subsection{Collateral}

Collateral is a basic contractual agreement that minimizes costs arising from adverse selection and problem of representation by allowing the bank to filter out risky businesses (16]) and by encouraging the selection of low risk projects ( [62]) as well as timely repayment of loans ( [19] and [43]). However, the theoretical framework suggests that collateral requirements may negatively affect the allocation of resources within the enterprise. For example, if your investment depends on the value of your collateral, your investment is usually below the optimal level; or the enterprise may hold assets that may be used as collateral such as land and other fixed assets at a level higher than the optimal level from the technical perspective ( [40]).

Previous studies have shown that information asymmetry in the assessment of investment projects between banks and firms may lead to lower loan value than expected ( [62]). Recent studies state that collateral can solve a particular kind of the information asymmetry problems mentioned above. The role of collateral in a loan contract reflects the motivation and signals effects of addressing the problem of adverse selection and moral hazard due to information asymmetry. If a loan is secured by a collateral, the business is less likely to choose a risky project. In addition, asset mortgages can force businesses to disclose potential risks. However, the use of collateral can be expensive for banks and businesses. Banks charge for the valuation and management of collateral as well as liquidation of collateral when the business loses liquidity. Businesses bearing high costs are required to prepare additional reports as required by the bank as well as costs due to restrictions on mortgage use rights ( [52]). The more special and illiquidity the collateral is, the more the cost related to collateral increases.

\section{METHODOLOGY}

\subsection{Research model}

We examine the impact of financial liberalization on collateral requirements by building a model in which the collateral requirement is a dependent variable and financial liberalization is the main explanatory variable. Mortgage requirements will in turn be measured in two respects: (i) the presence of the collateral requirement in the loan agreement and (ii) the size of the collateral against the loan. In addition to the main explanatory variable, we control for: (i) the characteristics of the enterprise and (ii) the characteristics of the country. Our research model is based on the model of factors that influence collateral requirements under [33]. 


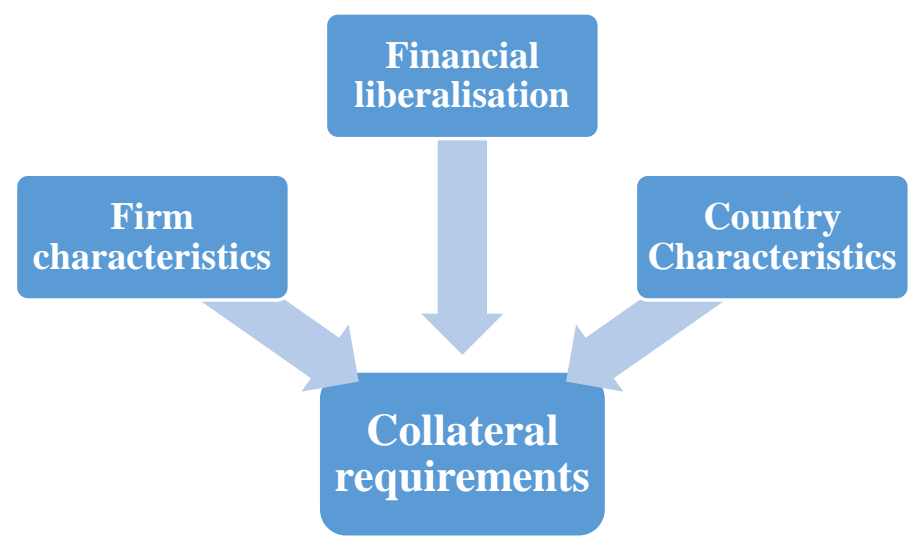

Figure 1: Research model

\subsection{Estimation method}

Most previous studies about mortgage related to the collateral requirements using a Probit regression model with a dummy variable representing the presence of collateral in the loan agreement (see [9]; [55]). However, discrete choice models such as Probit can hardly determine the exact size of required collateral. For example, a loan contract with a collateral comprising of $1 \%$ of contract value is encrypted the same as that of $100 \%$ of contract value and there is no difference between these two. In addition to the Probit and Logit models, studies such as [56], [60] used the Tobit regression model with dependent variable as the value ratio Mortgages on the value of the loan. In this study, besides examining of the impact of financial liberalization on the presence of collateral in loan contracts, we explore the impact of financial liberalization on the size of mortgage. Hence, we use the regression model Probit and Tobit respectively.

The Tobit model in our study has the form as follows:

$y_{i c s t}^{*}=x_{i c s t}^{\prime} \beta+u_{i c s t}$ với $u_{i c s t} \sim N\left(0, \sigma^{2}\right)$

Where $y_{i c s t}^{*}$ is the latent variable representing the ratio of the value of collateral to the value of the loan of enterprise I in country $\mathrm{c}$ in the sector $\mathrm{s}$ in year $\mathrm{t} ; x_{\text {icst }}$ is the vector of explanatory variables and $\beta$ is the corresponding estimation coefficient; and finally, $u_{\text {icst }}$ is the error that follows the normal distribution with constant variance. Due to $y_{i c s t}$, the real mortgage ratio, is always positive, the relationship between $y_{i c s t}^{*}$ and $y_{i c s t}$ is expressed as follows:

Log-likelihood for tobit model is as follows:

$$
\max \left(y_{i c s t}^{*}, 0\right)=y_{i c s t}
$$

$$
\log L=\sum_{y_{i c s t}=0} \ln \left[1-\eta\left(\frac{x_{i c s t}^{\prime} \beta}{\sigma}\right)\right]+\sum_{y_{i c s t}>0} \ln \left[\frac{1}{\sigma} \tau\left(\frac{y_{i c s t}-x_{i c s t}^{\prime} \beta}{\sigma}\right)\right]
$$

Where $\eta($.$) and \tau($.$) are cumulative distribution function and probability distribution function$ respectively.

To test the robustness of the research results, we perform the following two methods. Firstly, the regression results of the Probit model is compared to the Logit model. Second, the financial liberalization index (measured by the model in [1] and explained in details in the section 3.3), the main explanatory variable in the Probit, Logit and Tobit models are replaced by the control index capital ([35]).

\subsection{Measuring financial liberalization}

The three sets of commonly used measures of financial liberalization in the current regulatory framework include: (i) capital account liberalization, (ii) capital market liberalization and (iii) zone liberalization in the banking sector. In addition to the scales for each aspect of financial liberalization, we 
also have multidimensional scales of simultaneous consideration of financial liberalization. With the objective of assessing the impact of financial liberalization on the relationship between the financing and investment constraints of the firm, the study adopts a multidimensional approach to financial measurement by [1] with seven indicators related to financial liberalization as follows: (i) credit control and reserve requirements, (ii) interest rate controls, (iii) barriers to entry into the banking sector, (iv) state ownership in the banking sector, (v) control of capital accounts, (vi) safety regulation and supervision of the banking sector, and (vii) policies for the securities market. In each indicator, countries are rated on a scale from 0 to 3 with zero indicating the highest level of financial control and level 3 implies a full liberalization. The assessment is based on the annual report of the IMF countries. In case the information in the annual report is unclear, we refer to the report, newsletter and website of the central bank and the World Bank. The financial liberalization index is the sum of the scores of these seven norms after normalization in the interval of $[0,1]$.

\subsection{Variables and data}

In the first section, to test the impact of financial liberalization on the ability to request a collateral in a loan contract, we use a probit regression model with a dependent variable called coll1. The value is equal to 1 when the business needs to mortgage the property in the loan contract. The coll1 information comes from answering the question, "In the latest loan agreement signed with a financial institution, do businesses need a mortgage?" In the next step, we look at the effect of financial liberalization on the value of a collateral required by the Tobit regression model with coll2 dependent variable. Coll2 responds to the question, "What is the percentage of collateral value in the last loan agreement compared with the value of the loan?"

The explanation that we consider in the study is that the financial liberalization index fli is based on [1]. Besides the main explanatory variable, the study includes some of the characteristics of the enterprise and those of the country in the model. In the firm characteristic category, we include three variables that represent the risk of insolvency of the business: liq_risk, crime and overdue. liq_risk is measured by the ratio of the firm's sales revenue to total sales. Liq_risk represents the risk of losing business with the assumption that the higher sales ratio is, the less money the business holds. Overdue is a dummy variable with a value of 1 if the business has outstanding debts. Crime is also a dummy variable that is equal to 1 if one of the five businesses suffers damage from theft or vandalism. We expect financial institutions to be less willing to provide financing to businesses with poor liquidity, to fulfill current debt obligations and to operate in a less secure environment. Accordingly, financial institutions develop more stringent loan agreements (including collateral requirements) for high-risk businesses. So we expect the same relationship between the dependent variable and the three variables.

Next, the other control variables for the corporate characteristics are explained. The variable Industry representing companies in the production sector with the value of 0 or of 1 if the company in the service sector. In this research, we only specify the category in general (production and service) but not in details because the sample includes medium and small sized companies. In the service sector, companies usually have low fixed assets ratio, hence we expect services companies less likely face with collateral requirements (the industry parameter is less than 0 ). The variable size represents the company size, which is a dummy variable with the value of 0 if the company is medium and 1 if small. Small size companies are often young, promising and have higher risks. We expect size has the positive sign which implies that young companies increase the probability to request a collateral in a loan contract. The variable age is measured by the natural logarithm of the company age. Old companies can maintain a long relationship with lenders, hence they can negotiate loan contracts with less strict requirements such as low interest rates or less collateral. We expect the negative sign for the variable age. The variable sole_own is for the business type which has the value of 1 if the company is a limited liability company or partnership and 0 if the company is a sole proprietorship. The mortgage in the contract is valid when the contract can be enforced in reality. For the company having more than one owner, the contract enforcement can be hard; therefore, finance providers can abide the collateral requirements strictly. It is expected that sole_own has a negative sign. Quality has a value of 1 if the company has got ISO9000 or ISO9002. The fact that 
companies get ISO certificates implies that the company is credited and does not need tight collateral requirements. Consequently, the variable quality is expected to be negative.

Table 1: Definition of variables and information sources

\begin{tabular}{|c|c|c|}
\hline Variable & Definition & Source \\
\hline \multicolumn{3}{|l|}{ Collateral } \\
\hline coll1 & $\begin{array}{l}\text { The dummy variable equals } 1 \text { if the company has to mortgage the } \\
\text { property in the loan contract, otherwise } 0 .\end{array}$ & $\begin{array}{l}\text { Enterprise Surveys - World } \\
\text { Bank }\end{array}$ \\
\hline coll2 & The value of collateral value on the loan value. & $\begin{array}{l}\text { Enterprise Surveys - World } \\
\text { Bank }\end{array}$ \\
\hline \multicolumn{3}{|c|}{ Financial liberalization } \\
\hline Fli & Financial Liberalization Index & $\begin{array}{l}\text { Author calculated based on } \\
\text { research of Abiad et al. } \\
(2010)\end{array}$ \\
\hline kacon & Capital control index & Fernandez et al. (2016) \\
\hline \multicolumn{3}{|c|}{ Firm characteristics } \\
\hline industry & $\begin{array}{l}\text { The dummy variable is equal to } 1 \text { if the enterprise is in the service } \\
\text { sector and } 0 \text { if the enterprise in the manufacturing sector }\end{array}$ & $\begin{array}{l}\text { Enterprise Surveys - World } \\
\text { Bank }\end{array}$ \\
\hline Size & $\begin{array}{l}\text { The dummy variable equals to } 1 \text { if the enterprise is small (5-19 } \\
\text { workers) and } 0 \text { if it is a medium sized enterprise (20-99 employees). }\end{array}$ & $\begin{array}{l}\text { Enterprise Surveys - World } \\
\text { Bank }\end{array}$ \\
\hline Age & Natural logarithm of number of years of operation. & $\begin{array}{l}\text { Enterprise Surveys - World } \\
\text { Bank }\end{array}$ \\
\hline sole_own & $\begin{array}{l}\text { The dummy variable is } 1 \text { if the business has one owner, otherwise it } \\
\text { is zero. }\end{array}$ & $\begin{array}{l}\text { Enterprise Surveys - World } \\
\text { Bank }\end{array}$ \\
\hline quality & $\begin{array}{l}\text { The price variable is equal to } 1 \text { if the enterprise has a certificate of } \\
\text { quality which is internationally recognized as ISO9000 or ISO } 9002 \text {, } \\
\text { otherwise } 0 .\end{array}$ & $\begin{array}{l}\text { Enterprise Surveys - World } \\
\text { Bank }\end{array}$ \\
\hline Crime & $\begin{array}{l}\text { The dummy equals to } 1 \text { if the business has a damage due to robbery } \\
\text { or vandalism, otherwise } 0 \text {. }\end{array}$ & $\begin{array}{l}\text { Enterprise Surveys - World } \\
\text { Bank }\end{array}$ \\
\hline liq_risk & Turnover sales over total revenue. & $\begin{array}{l}\text { Enterprise Surveys - World } \\
\text { Bank }\end{array}$ \\
\hline overdue & $\begin{array}{l}\text { The dummy variable is } 1 \text { if the business has outstanding debts, } \\
\text { otherwise } 0 .\end{array}$ & $\begin{array}{l}\text { Enterprise Surveys - World } \\
\text { Bank }\end{array}$ \\
\hline \multicolumn{3}{|c|}{ Country characteristics } \\
\hline info_shr & $\begin{array}{l}\text { Depth of credit information index. } \\
\text { Prior to } 2013 \text {, this indicator was measured in }[0,6] \text {; from } 2013 \text { in }[0 \text {, } \\
\text { 8]. The author normalizes this index in }[0,1]\end{array}$ & $\begin{array}{l}\text { Doing Business - World } \\
\text { Bank }\end{array}$ \\
\hline
\end{tabular}

In addition to business characteristics, the study also controls macroeconomic characteristics which likely affect collateral requirements. The variable representing the macro environment is the variable info_shr measured by the financial information depth index. The financial information depth index reflects regulations that affect the scope, accessibility and quality of public and private information. This indicator has been provided by World Bank since 2004. In the period 2004-2012, the index is in the interval of $[0,6]$. In the period of 2013, it is in $[0,8]$. In order to overcome this variation, we standardize the depth of financial information in 2009 and 2015 in [0, 1]. Brown et al. [20] provided an evidence that information sharing can help expand the access of credit of businesses. We expect that information sharing may limit the requirements for collateral or in other words, the coefficient of info_shr is negative. Detailed variables and data sources can be found in Table 1.

The study uses secondary data on small and medium enterprises in the World Bank's Enterprise Survey database. According to the classification of the World Bank, enterprises with 5-19 full-time employees are considered as small-scale enterprises, one with between 20 and 99 employees are considered as medium-sized enterprises. Enterprises with less than 5 employees are considered micro 
enterprises. In the sample of three low-income countries in Southeast Asia (Vietnam, Indonesia and the Philippines), the number of observations coming from microenterprises is negligible (17 in total number 1.105), the authors combine these observations in the small scale group. Enterprise Surveys are not implemented at certain intervals. For example, in the three study countries, Vietnam has the Enterprise Survey data for 2005, 2009 and 2015, while Indonesia and the Philippines only have data for 2009 and 2015. In order to ensure the proportion of data, Experimental data on the 2009 and 2015 data for the three countries mentioned above. Besides micro data from the Enterprise Surveys database, the study uses some of the macro data from the World Bank's Doing Business database. After excluding the insufficient observations of the variables measured in the model, there are 1,105 observations for 792 enterprises.

\section{RESULTS}

\subsection{Descriptive statistics results}

The descriptive statistics for the whole sample are shown in Table 2. In addition to the statistical results for the whole sample, the study presents statistical results for each country and for each year in Appendix 1 and 2.

Table 2: Descriptive statistics results

\begin{tabular}{|c|c|c|c|c|c|}
\hline Variable & Observations & Mean & Std Error & Min & Max \\
\hline \multicolumn{6}{|l|}{ Collateral } \\
\hline coll1 & 1,105 & 0.28 & 0.45 & 0.00 & 1.00 \\
\hline coll2 & 219 & 23.56 & 301.20 & 0.17 & $4,500.00$ \\
\hline \multicolumn{6}{|c|}{ Financial liberalization } \\
\hline Fli & 1,105 & 0.59 & 0.13 & 0.30 & 0.71 \\
\hline Kacon & 1,105 & 0.80 & 0.12 & 0.63 & 0.90 \\
\hline \multicolumn{6}{|c|}{ Firm characteristics } \\
\hline industry & 1,105 & 0.30 & 0.46 & 0.00 & 1.00 \\
\hline Size & 1,105 & 0.51 & 0.50 & 0.00 & 1.00 \\
\hline Age & 1,105 & 2.78 & 0.65 & 0.69 & 4.48 \\
\hline sole_own & 1,105 & 0.48 & 0.50 & 0.00 & 1.00 \\
\hline quality & 1,105 & 0.12 & 0.33 & 0.00 & 1.00 \\
\hline Crime & 1,105 & 0.14 & 0.35 & 0.00 & 1.00 \\
\hline liq_risk & 1,105 & 0.46 & 0.41 & 0.00 & 1.00 \\
\hline overdue & 1,105 & 0.20 & 0.40 & 0.00 & 1.00 \\
\hline \multicolumn{6}{|c|}{ "Country characteristics } \\
\hline info_shr & 1,105 & 0.67 & 0.12 & 0.50 & 0.88 \\
\hline
\end{tabular}

\subsection{Estimation results}

The results of the estimation and test of the research model are presented in Table 3. Columns (1) in Table 3 shows the results of the Probit regression model with the dependent variable of coll1 to examine the impact of financial liberalization on the presence of collateral requirements in the loan agreement. The results show that financial liberalization increases the likelihood that businesses have to mortgage their property at the confidence interval of $1 \%$. Thus, in financial research countries, financial liberalization has a negative impact on access to external sources of financing by SMEs. As mentioned in the literature review, financial liberalization has the potential to exacerbate information asymmetry as well as undermining the relationship between business and financial intermediaries. From the perspective of 
Vietnamese SMEs, financial liberalization does not solve obstacles in the capital mobilization of enterprises but vice versa.

Table 3: Estimation and verified results

\begin{tabular}{|c|c|c|c|}
\hline \multirow[t]{2}{*}{ Model } & (1) & (2) & \multirow{2}{*}{$\frac{\text { (3) }}{\text { Tohit }}$} \\
\hline & Probit & Logit & \\
\hline Variable & coll1 & coll1 & coll2 \\
\hline Financial liberalization & & & \\
\hline & $\begin{array}{r}28.74 * * * * \\
3.56\end{array}$ & $\begin{array}{r}77.41 * * * \\
8.47\end{array}$ & $\begin{array}{l}304.40 \\
304.20\end{array}$ \\
\hline Firm characteristics & & & \\
\hline industry & $\begin{array}{r}-0.225^{*} \\
0.14\end{array}$ & $\begin{array}{r}-0.36 \\
0.23\end{array}$ & $\begin{array}{r}-50.65 \\
4763\end{array}$ \\
\hline Size & -0.15 & -0.28 & -52.23 \\
\hline & 0.12 & 0.21 & 51.07 \\
\hline Age & 0.08 & 0.12 & -73.77 \\
\hline & 0.10 & 0.16 & 71.64 \\
\hline sole_own & 0.12 & 0.21 & 50.78 \\
\hline & 0.13 & 0.23 & 50.41 \\
\hline quality & $-0.383 * *$ & $-0.600 *$ & -26.51 \\
\hline & 0.19 & 0.33 & 27.35 \\
\hline Crime & $0.369^{* *}$ & $0.605^{* *}$ & -34.42 \\
\hline & 0.15 & 0.25 & 35.10 \\
\hline liq_risk & 0.24 & 0.36 & -92.02 \\
\hline & 0.16 & 0.28 & 88.02 \\
\hline overdue & $7.769 * * *$ & $21.21 * * *$ & -161.60 \\
\hline & 0.39 & 0.91 & 156.10 \\
\hline Country characteristics & & & \\
\hline info_shr & $\begin{array}{r}-54.48 * * * \\
3.30\end{array}$ & $\begin{array}{r}-155.4 * * * \\
7.27\end{array}$ & $\begin{array}{r}1,051.00 \\
999.70\end{array}$ \\
\hline Constant & $\begin{array}{r}17.36^{* * * *} \\
0.53\end{array}$ & 52.06 & $\begin{array}{r}-545.00 \\
530.50\end{array}$ \\
\hline Country FE & Yes & Yes & Yes \\
\hline Year FE & Yes & Yes & Yes \\
\hline No. of observations & 1,105 & 1,105 & 219 \\
\hline Log likelihood & -295.43 & -296.19 & $-1,555.46$ \\
\hline Pseudo $\mathrm{R}^{2}$ & 0.55 & 0.55 & \\
\hline Sigma & & & $294.0^{* * *}$ \\
\hline
\end{tabular}

Note: The standard deviation is italicized and is expressed below the estimated coefficient. ***, ** and * represent the confidence interval at 1\%, 5\% and $10 \%$ respectively.

Some causes may explain the situation mentioned above. First, the process of financial liberalization makes it easier for foreign financial institutions to participate the domestic financial market. However, this does not mean that SMEs will have easy access to financial resources from foreign institutions. SMEs with high levels of risk and poor accounting information systems will increase the cost of verifying information and that of implementing contracts. Financial institutions can offset this expense by raising interest rates. However, raising interest rates will lead to adverse selection. Foreign financial institutions, in order to secure debt recovery, will increase the requirement for collateral. Second, in the process of financial liberalization, domestic financial institutions are exposed to competitive pressure. Hence, the rate of return is declining. With declining margins, domestic organizations will be more cautious and thus develop more stringent loan agreements including mortgage terms. Third, financial liberalization has increased the number of financial institutions. Businesses in general and SMEs in particular have more 
choices. Businesses do not necessarily maintain a long-term relationship with a financial provider. As a result, the information asymmetry between financial institutions and enterprises has not decreased, resulting that loan terms are not adjusted in favor of the business.

Table 4: Results of robustness check

\begin{tabular}{|c|c|c|c|}
\hline \multirow[t]{2}{*}{ Model } & (4) & (5) & (6) \\
\hline & Probit & Logit & Tobit \\
\hline Variable & coll1 & coll1 & Coll2 \\
\hline Financial liberalization & & & \\
\hline Kacon & $\begin{array}{r}-232.60 \\
0.00\end{array}$ & $\begin{array}{r}-590.00 \\
0.00\end{array}$ & $\begin{array}{r}-412.20 \\
412.00\end{array}$ \\
\hline Firm characteristics & & & \\
\hline Industry & $-0.225^{*}$ & $\begin{array}{r}-0.36 \\
0.23\end{array}$ & $\begin{array}{r}-50.65 \\
17.63\end{array}$ \\
\hline Size & -0.15 & -0.28 & -52.23 \\
\hline & 0.12 & 0.21 & 51.07 \\
\hline Age & 0.08 & 0.12 & -73.77 \\
\hline & 0.10 & 0.16 & 71.64 \\
\hline sole_own & 0.12 & 0.21 & 50.78 \\
\hline & 0.13 & 0.23 & 50.41 \\
\hline Quality & $-0.383 * *$ & $-0.600 *$ & -26.51 \\
\hline & 0.19 & 0.33 & 27.35 \\
\hline Crime & $0.369^{* *}$ & $0.605^{* *}$ & -34.42 \\
\hline & 0.15 & 0.25 & 35.10 \\
\hline liq_risk & 0.24 & 0.36 & -92.02 \\
\hline & 0.16 & 0.28 & 88.02 \\
\hline Overdue & $7.769 * * *$ & $19.84 * * *$ & -238.60 \\
\hline & 0.76 & 1.70 & 231.80 \\
\hline Country characteristics & & & \\
\hline info_shr & $\begin{array}{r}-56.12 * * * \\
5.28\end{array}$ & $\begin{array}{r}-148.8 * * * \\
12.61\end{array}$ & $\begin{array}{l}1,649.00 \\
1,583.00\end{array}$ \\
\hline Constant & $180.6 * * *$ & $462.1 * * *$ & -483.00 \\
\hline & 3.25 & 7.85 & 471.00 \\
\hline Country FE & Yes & Yes & Yes \\
\hline Year FE & Yes & Yes & Yes \\
\hline $\begin{array}{l}\text { No. of observations } \\
\text { Sioma }\end{array}$ & 1,105 & 1,105 & 219 \\
\hline
\end{tabular}

Note: The standard deviation is italicized and is expressed below the estimated coefficient. ***, ** and * represent the confidence interval at $1 \%, 5 \%$ and $10 \%$ respectively.

In the group of enterprise-specific factors, the groups representing the risk of insolvency including crime, liq_risk and overdue all have positive signs and the statistical significance (except for variables liq_risk). This means that there is a positive relationship between the collateral requirement and the risk profile of the business. The results also show that having a certificate of quality management is an important factor in reducing the probability of collateral requirements. Firms in the service sector have a lower probability of collateral under loan contracts than those in the manufacturing sector. This may come from property characteristics of service enterprises with the majority of intangible assets. The variable representing the national average, info_shr, has a negative correlation and is statistically significant with the ability of the firm to bind the collateral in the loan contract. Thus, a transparent information sharing mechanism will help reduce collateral requirements for SMEs by reducing information asymmetry between enterprises and financial providers. In addition to the Probit model, the authors also use the Logit model to look at the impact of financial liberalization on the asset collateral of the business. Generally, the regression coefficients of the two models have similar signs and statistical significance. 


\section{FINANCIAL LIBERALIZATION AND COLLATERAL REQUIREMENTS OF SMALL AND MEDIUM ENTERPRISES - EVIDENCE FROM SOUTH-EAST ASIAN LOWER AND MIDDLE INCOME COUNTRIES}

After examining the impact of financial liberalization on the ability of firms to mortgage their assets in a loan agreement, the authors continue to analyze the impact of this factor on collateral size through Tobit regression. Tobit regression results are shown in Column (3) in Table 3. Tobit regression results show that financial liberalization is positively correlated with the magnitude of collateral required. However, this result is not statistically significant. This result may be due to the limitation of data, quantitative (there are only 219 observations) and qualitative. During the analysis of data, the authors finds that the value of the collateral against the loan is often left blank. Despite the lack of statistical significance, the results of the impact of financial liberalization on the size of mortgages in the Tobit model may be suggestive for later reasearch.

For the purposes of testing the robustness of the results, the authors replace the main explanatory variable in the model - the financial liberalization index by the capital control index proposed by Fernandez et al. [35]. Capital control index measure the level of control over capital accounts of countries. Due to the contrary in their nature, it is expected that the capital control index - kacon has the opposite sign with the financial liberalization index. The results shown in Table 4 confirm this expectation by indicating that kacon is negatively correlated with coll1. This means that a high level of capital controls is likely to reduce the presence of collateral requirements for SMEs.

\section{CONCLUSION}

The study was conducted with a view to examining the impact of financial liberalization on collateral requirements for SMEs in low-income and middle-income economies in Southeast Asia. The results suggest that financial liberalization has a negative impact on the presence of collateral requirements while the information depth likely improves the problem. This result suggests that asymmetric information is the decisive factor for collateral requirements. In order to solve the problem of collateral for SMEs, it is necessary to address the problem of information asymmetry. A transparent information sharing mechanism is likely to limit the collateral requirement for businesses. Information transparency, however, is not a satisfactory factor for SMEs. Subjectively, SMEs lack resources in term of finance as well as skilled staff. Objectively, institutional factors in developing countries do not create incentives for business transparency. However, SMEs can gradually improve information transparency through the development of effective accounting information system. With an effective information system, companies can benefit from the process of financial liberalization.

\section{REFERENCES}

[1] Abiad A., Detragiache E. and Tressel T. (2010). A New Database of Financial Reforms. IMF Staff Papers, Palgrave Macmillan, vol. 57(2), pages 281302, June.

[2] Adler D. (2014). The New Economics of Liquidity and Financial Frictions. The CFA Institute Research Foundation: www.cfapubs.org.

[3] Andersen, T. and Tarp, F. (2003). Financial Liberalization, Financial Development and Economic Growth in LDCs. Journal of International Development 15, 189-209

[4] Aristei, D., Perali, F., Pieroni, L., Cohort, age and time effects in alcohol consumption by Italian households: a double-hurdle approach. Empirical Economics 35, 29-61, 2008.

[5] Baas, T., Schrooten, M., Relationship banking and SMEs: a theoretical analysis. Small Business Economics 27, 127-137, 2006.

[6] Beck, T., Demirguc-Kunt, A., Laeven, L., Maksimovic, V., The determinants of financing obstacles. Journal of International Money and Finance 25, 932-952, 2006.

[7] Berger, A.N., Udell, G.F., Collateral, loan quality, and bank risk. Journal of Monetary Economics 25, 21-42, 2006. 
[8] Berger, A.N., Udell, G.F., Relationship lending and lines of credit in small firm finance. Journal of Business 68, 351-381, 1995.

[9] Berger, A.N., Udell, G.F., A more complete conceptual framework for SME finance. Journal of Banking and Finance 30, 2945-2966; 2006.

[10] Berger, A.N., Klapper, L.F., Udell, G.F., The ability of banks to lend to informationally opaque small businesses. Journal of Banking and Finance 25, 2127-2167; 2001.

[11] Berger, A.N., Frame, W.S., Ioannidou, V., Tests of ex ante versus ex post theories of collateral using private and public information. Journal of Financial Economics 100, 85-97, 2011a.

[12] Berger, A.N., Espinosa-Vega, M.A., Frame, W.S., Miller, N.H., Why do borrowers pledge collateral? New empirical evidence on the role of asymmetric information. Journal of Financial Intermediation 20, 55-70, 2011b.

[13] Berlin, M., Butler, A.W., Collateral and Competition. Working Paper, Federal Reserve Bank of Philadelphia, 2002.

[14] Besanko, D., Thakor, A.V., Collateral and rationing: sorting equilibria in monopolistic and competitive credit markets. International Economic Review 28, 671-689, 1987.

[15] Bester, H., The role of collateral in credit markets with imperfect information. European Economic Review 31, 887-899, 1987.

[16] Boot, A.W.A., Thakor, A.V., Moral hazard and secured lending in an infinitely repeated credit market game. International Economic Review 35, 899-920, 1994.

[17] Boot, A.W.A., Thakor, A.V., Can relationship banking survive competition? The Journal of Finance 55, 679713, 2000.

[18] Boot, A.W.A., Thakor, A.V., Udell, G.F., Secured lending and default risk: equilibrium analysis, policy implications and empirical results. The Economic Journal 101, 458-472, 1991.

[19] Brown, M., Jappelli, T., Pagano, M., Information sharing and credit: firm-level evidence from transition countries. Journal of Financial Intermediation 18, 151-172, 2009.

[20] Brick, I.E., Palia, D., Evidence of jointness in the terms of relationship lending. Journal of Financial Intermediation 16, 452-476, 2007.

[21] Caballero, R.J., Krishnamurthy, A., International and domestic collateral constraints in a model of emerging market crises. Journal of Monetary Economics 48, 513-548, 2001.

[22] Chakraborty, A., Hu, C.X., Lending relationships in line-of-credit and nonlineof-credit loans: evidence from collateral use in small business. Journal of Financial Intermediation 15, 86-107, 2006.

[23] Chan, Y.S., Kanatas, G., Asymmetric valuations and the role of collateral in loan agreements. Journal of Money, Credit and Banking 17, 84-95, 1985.

[24] Chan, Y.S., Thakor, A.V., Collateral and competitive equilibria with moral hazard and private information. The Journal of Finance 42, 345-363, 1987.

[25] Chen, Y., Collateral, loan guarantees, and the lenders' incentives to resolve financial distress. The Quarterly Review of Economics and Finance 46, 1-15, 2006. 
[26] Coco, G., Collateral, heterogeneity in risk attitude and the credit market equilibrium. European Economic Review 43, 559-574, 1999.

[27] Cressy, R., Toivanen, O., Is there adverse selection in the credit market? Venture Capital 3, 215-238, 2001.

[28] Degryse, H., Van Cayseele, P., Relationship lending within a bank-based system: evidence from European small business data. Journal of Financial Intermediation 9, 90-109, 2000.

[29] Diamond D. W. and Dybvig P. H. (1983). "Bank runs, deposit insurance, and liquidity". Journal of Political Economy. 91 (3): 401-419.

[30] Dionne, G., Artis, M., Guillen, M., Count data models for a credit scoring system. Journal of Empirical Finance 3, 303-325, 1996.

[31] Demirgüç-Kunt, A. and Detragiache E. (1998). Financial Liberalization and Financial Fragility. IMF Working Paper, 98/83, 1998.

[32] Duarte, Fabio Dias, Gama, Ana Paula Matias, Esperanc' ,a, Jose’ Paulo, Collateral-based in SME lending: The Role of Business Collateral and Personal Collateral in Less-Developed Countries. Research in International Business and Finance.

[33] Feder, G., Tongroj, O., Tejaswi, R., Collateral, guaranties and rural credit in developing countries: evidence from Asia. Agricultural Economics 2, 231-245, 1988.

[34] Fernandez, A., Klein M., Rebucci A., Schindler M., and Uribe M. (2016). Capital Control Measures: A New Dataset. IMF Economic Review, 64, 2016, 548574.

[35] Geanakoplos, J., and Zame W. R. (2013). Collateral Equilibrium: A Basic Framework. Cowles Foundation Discussion Paper No. 1906, Yale University.

[36] Gelos, G., Werner, A.M., Financial liberalization, credit constraints, and collateral: investment in the Mexican manufacturing sector. Journal of Development Economics 67, 1-27, 2002.

[37] Godlewski, C.J., Weill, L., Does collateral help mitigate adverse selection? A cross-country analysis. Journal of Financial Services Research 40, 49-78, 2011.

[38] Gonas, J., Highfield, M.J., Mullineaux, D.J., When are commercial loans secured. The Financial Review 39, 79-99., 2004.

[39] Gottardi, P., and F. Kubler, (2015). Dynamic Competitive Economies with Complete Markets and Collateral Constraints. Review of Economic Studies, 82: 11191153.

[40] Guermazi A. (2014). Financial Liberalization, Credit Constraints and Collateral: The case of Manufacturing Industry in Tunisia. Procedia Economics and Finance, 13 (2014), 82 - 100.

[41] Hainz, C., Bank competition and credit markets in transition economies. Journal of Comparative Economics 31, 223-245, 2003.

[42] Hainz, C., Weill, L., Godlewski, C.J., Bank competition and collateral: theory and evidence. Journal of Financial Services Research 44, 131-148, 2013.

[43] Hanedar, E. Y., Broccardo, E., Bazzana, F. Collateral requirements of SMEs: The evidence from lessdeveloped countries. Journal of Banking and Finance 38, 106-121, 2014b. 
[44] Hart, O., and J. Moore, (1994). A Theory of Debt Based on the Inalienability of Human Capital.Quarterly Journal of Economics, 109: 841-879.

[45] Hellmann, Murdock, and Stiglitz, "Liberalization, Moral Hazard in Banking, and Prudential Regulation: Are Capital Requirements Enough,” American Economic Review 90, 1 (2000), pp. 147-165.

[46] Jiménez, G., Salas, V., Saurina, J., Determinants of collateral. Journal of Financial Economics 81, 255-281, 2006.

[47] Jiménez, G., Salas, V., Saurina, J., Organizational distance and use of collateral for business loans. Journal of Banking and Finance 33, 234-243, 2009.

[48] Jiménez, G., Salas, V., Saurina, J., The effects of formal and informal contracting in credit availability. Journal of Money, Credit and Banking 43, 109-132, 2011.

[49] Jiménez, G., Saurina, J., Collateral, type of lender and relationship banking as determinants of credit risk. Journal of Banking and Finance 28, 2191-2212, 2004.

[50] Laeven, L. (2003). Does Financial Liberalization Reduce Financial Constraints? Financial Management, 32, 5 34.

[51] Leeth, J. and Scott, J. (1989). The Incidence of Secured Debt: Evidence from the Small Business Community. Journal of Financial and Quantitative Analysis, 24, 379-394.

[52] Liberti, J.M., Mian, A.R., Collateral spread and financial development. Journal of Finance 65, 147-177, 2010.

[53] McKinnon, R. I. (1973). Money and capital in economic development. Washington, DC: Brookings Institutions.

[54] Menkhoff, L., Neuberger, D., Rungruxsirivorn, O., Collateral and its substitutes in emerging markets' lending. Journal of Banking and Finance 36, 817-834, 2012.

[55] Menkhoff, L., Neuberger, D., Suwanaporn, C., Collateral-based lending in emerging markets: evidence from Thailand. Journal of Banking and Finance 30, 1-21, 2006.

[56] Myers, S. C. and N. S. Majluf (1984). Corporate Financing and Investment Decisions When Firms Have Information That Investors Do Not Have. Journal of Financial Economics, 13, 187-221.

[57] Niinimäki, J.-P., Does collateral fuel moral hazard in banking? Journal of Banking and Finance 33, 514-521, 2009.

[58] Pagano, M., Jappelli, T., Information sharing in credit markets. The Journal of Finance 43, 1693-1718, 1993.

[59] Peltoniemi, J., Collateral Requirements and relationship banking: empirical evidence from unique Finnish credit-files. The Finnish Journal of Business Economics 11, 393-414, 2007.

[60] Shaw, E. S. (1973). Financial deepening in economic development. New York: Oxford University Press.

[61] Stiglitz, J.E., Weiss, A., Credit rationing in markets with imperfect information. The American Economic Review 71, 393-410, 1981.

[62] Stiglitz, J. E. (2002). Globalization and Its Discontents. New York: W.W.Norton.

[63] Voordeckers, W., Steijvers, T., Business collateral and personal commitments in SME lending. Journal of Banking and Finance 30, 3067-3086, 2006. 


\section{APPENDIX 1}

Descriptive result by nation

\begin{tabular}{|c|c|c|c|c|c|c|c|c|c|c|c|c|c|c|c|}
\hline \multirow{2}{*}{$\begin{array}{l}\text { Nation } \\
\text { Variable }\end{array}$} & \multicolumn{5}{|c|}{ Indonesia } & \multicolumn{5}{|c|}{ Philippines } & \multicolumn{5}{|c|}{ Vietnam } \\
\hline & Obs & Mean & S.E & Min & Max & Obs & Mean & S.E & Min & Max & Obs & Mean & S.E & Min & Max \\
\hline \multicolumn{16}{|l|}{ Collateral } \\
\hline coll1 & 357 & 0.25 & 0.43 & 0.00 & 1.00 & 527 & 0.17 & 0.37 & 0.00 & 1.00 & 271 & 0.54 & 0.50 & 0.00 & 1.00 \\
\hline coll2 & 40 & 3.16 & 3.86 & 1.00 & 25.00 & 49 & 2.45 & 2.28 & 0.17 & 14.29 & 134 & 37.38 & 388.50 & 0.25 & 4500.00 \\
\hline \multicolumn{16}{|c|}{ Financial liberalization } \\
\hline fli & 357 & 0.58 & 0.00 & 0.58 & 0.58 & 527 & 0.71 & 0.00 & 0.70 & 0.71 & 271 & 0.39 & 0.10 & 0.30 & 0.49 \\
\hline kacon & 357 & 0.63 & 0.00 & 0.63 & 0.63 & 527 & 0.88 & 0.00 & 0.88 & 0.88 & 271 & 0.89 & 0.01 & 0.88 & 0.90 \\
\hline \multicolumn{16}{|c|}{ Firm characteristics } \\
\hline industry & 357 & 0.23 & 0.42 & 0.00 & 1.00 & 527 & 0.29 & 0.45 & 0.00 & 1.00 & 271 & 0.40 & 0.49 & 0.00 & 1.00 \\
\hline size & 357 & 0.59 & 0.49 & 0.00 & 1.00 & 527 & 0.51 & 0.50 & 0.00 & 1.00 & 271 & 0.41 & 0.49 & 0.00 & 1.00 \\
\hline age & 357 & 2.91 & 0.52 & 1.39 & 4.48 & 527 & 2.94 & 0.62 & 0.69 & 4.39 & 271 & 2.31 & 0.62 & 0.69 & 4.06 \\
\hline sole_own & 357 & 0.72 & 0.45 & 0.00 & 1.00 & 527 & 0.36 & 0.48 & 0.00 & 1.00 & 271 & 0.41 & 0.49 & 0.00 & 1.00 \\
\hline quality & 357 & 0.05 & 0.21 & 0.00 & 1.00 & 527 & 0.20 & 0.40 & 0.00 & 1.00 & 271 & 0.07 & 0.26 & 0.00 & 1.00 \\
\hline crime & 357 & 0.04 & 0.19 & 0.00 & 1.00 & 527 & 0.22 & 0.41 & 0.00 & 1.00 & 271 & 0.14 & 0.34 & 0.00 & 1.00 \\
\hline liq_risk & 357 & 0.18 & 0.29 & 0.00 & 1.00 & 527 & 0.59 & 0.41 & 0.00 & 1.00 & 271 & 0.56 & 0.36 & 0.00 & 1.00 \\
\hline overdue & 357 & 0.28 & 0.45 & 0.00 & 1.00 & 527 & 0.12 & 0.33 & 0.00 & 1.00 & 271 & 0.23 & 0.42 & 0.00 & 1.00 \\
\hline \multicolumn{16}{|c|}{ Country characteristics } \\
\hline info_shr & 357 & 0.75 & 0.00 & 0.75 & 0.75 & 527 & 0.56 & 0.06 & 0.50 & 0.63 & 271 & 0.77 & 0.10 & 0.67 & 0.88 \\
\hline
\end{tabular}

\section{APPENDIX 2}

\section{Descriptive result by year}

\begin{tabular}{|c|c|c|c|c|c|c|c|c|c|c|}
\hline \multirow{2}{*}{$\begin{array}{c}\text { Year } \\
\text { Variable }\end{array}$} & \multicolumn{5}{|c|}{2009} & \multicolumn{5}{|c|}{2015} \\
\hline & Observation & Mean & $\begin{array}{c}\text { Std. } \\
\text { Error }\end{array}$ & Min & $\operatorname{Max}$ & Observation & Mean & $\begin{array}{c}\text { Std. } \\
\text { Error }\end{array}$ & Min & $\operatorname{Max}$ \\
\hline \multicolumn{11}{|l|}{ Collateral } \\
\hline coll1 & 397 & 0.35 & 0.48 & 0.00 & 1.00 & 758 & 0.24 & 0.43 & 0.00 & 1.00 \\
\hline coll2 & 115 & 3.58 & 5.66 & 0.25 & 40.00 & 108 & 44.84 & 432.70 & 0.17 & 4500.00 \\
\hline \multicolumn{11}{|c|}{ Financial liberalization } \\
\hline Fli & 397 & 0.57 & 0.20 & 0.30 & 0.71 & 758 & 0.61 & 0.08 & 0.49 & 0.70 \\
\hline Kacon & 397 & 0.88 & 0.01 & 0.88 & 0.90 & 758 & 0.76 & 0.13 & 0.63 & 0.88 \\
\hline \multicolumn{11}{|c|}{ Firm characteristics } \\
\hline industry & 397 & 0.32 & 0.47 & 0.00 & 1.00 & 758 & 0.28 & 0.45 & 0.00 & 1.00 \\
\hline Size & 397 & 0.50 & 0.50 & 0.00 & 1.00 & 758 & 0.52 & 0.50 & 0.00 & 1.00 \\
\hline Age & 396 & 2.56 & 0.74 & 0.69 & 4.38 & 758 & 2.90 & 0.56 & 0.69 & 4.48 \\
\hline sole_own & 397 & 0.31 & 0.46 & 0.00 & 1.00 & 758 & 0.57 & 0.50 & 0.00 & 1.00 \\
\hline quality & 397 & 0.16 & 0.37 & 0.00 & 1.00 & 758 & 0.10 & 0.30 & 0.00 & 1.00 \\
\hline Crime & 397 & 0.22 & 0.42 & 0.00 & 1.00 & 758 & 0.10 & 0.30 & 0.00 & 1.00 \\
\hline liq_risk & 397 & 0.66 & 0.39 & 0.00 & 1.00 & 758 & 0.35 & 0.37 & 0.00 & 1.00 \\
\hline overdue & 397 & 0.00 & 0.00 & 0.00 & 0.00 & 758 & 0.30 & 0.46 & 0.00 & 1.00 \\
\hline \multicolumn{11}{|c|}{ Country characteristics } \\
\hline info_shr & 397 & 0.56 & 0.08 & 0.50 & 0.67 & 758 & 0.73 & 0.09 & 0.63 & 0.88 \\
\hline
\end{tabular}

